\title{
Screening lead workers for the presence of stippled erythrocytes
}

\author{
R. L. CLARK, J. H. JONES, AND J. F. JONES \\ From the Department of Haematology, Royal Gwent Hospital, Newport, Mon.
}

SYNOPSIS The number of stippled erythrocytes in the blood of lead workers counted under dark ground microscopy show a marked fall when blood is taken into an anticoagulant. The significance of this finding is studied and alternative methods of screening workers are examined.

It has long been recognized that the presence of red cells in the peripheral blood showing basophilic stippling is a feature of lead intoxication, and an assessment of their numbers has been widely used as an indication of excessive absorption by lead workers.

A fortuitous finding that the high stippled cell counts in capillary blood films from lead workers were not seen in films prepared from venous blood taken into an anticoagulant seemed to be an observation worth recording in order to draw attention to the dangers of false low results in such specimens, and prompted an investigation into the phenomenon in an endeavour to throw some light on the nature and formation of stippled cells.

\section{MATERIALS AND METHODS}

Individuals were selected from local industrial concerns who were exposed to lead oxide and showed a stippled cell count in excess of 6,000 per million red cells as estimated by the method suggested by Lane (1949). These could all be regarded as showing evidence of excessive lead absorption, the criterion of which, using this method, is a count greater than 5,000 per million red cells. Both capillary and venous blood was taken

Received for publication 20 September 1966. from each individual and films were prepared immediately. In addition, films were made from the venous specimens after a varying period of time in a variety of anticoagulants.

The dried films were, at first, stained with $0.5 \%$ alkaline methylene blue in accordance with Lane's method, but later $1 \%$ new methylene blue was used, staining for $15 \mathrm{~min}$., and subsequently washing off with tap water.

The technique for reticulocyte staining was that suggested by Breecher (1949) using $1 \%$ new methylene blue in citrate-saline as a vital stain.

The serum haptoglobulin was estimated by the agar diffusion method of Rowe (1961).

\section{RESULTS}

Although stippled cells can be seen in blood films of lead workers stained with alkaline methylene blue in transmitted light, it was pointed out by Lane that these cells were much more easily identified by examination under dark ground illumination when the stipples appear as bright golden granules in the red cell (Fig. 1). The difficulty we experienced with this staining technique lies in the differentiation with tap water which is continued until a purely arbitrary sea green colour is reached, so that con-

TABLE I

STIPPLED CELLS/MILLION R.B.C.S

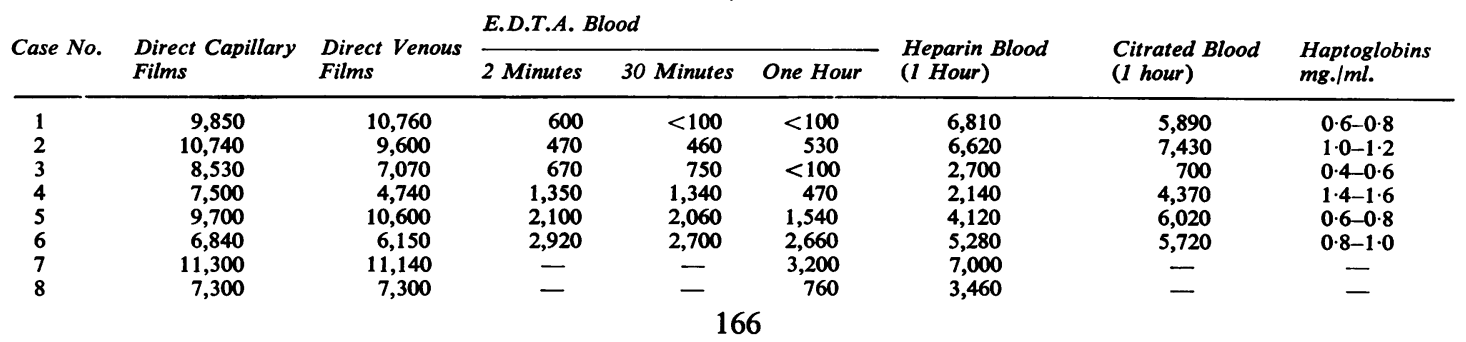




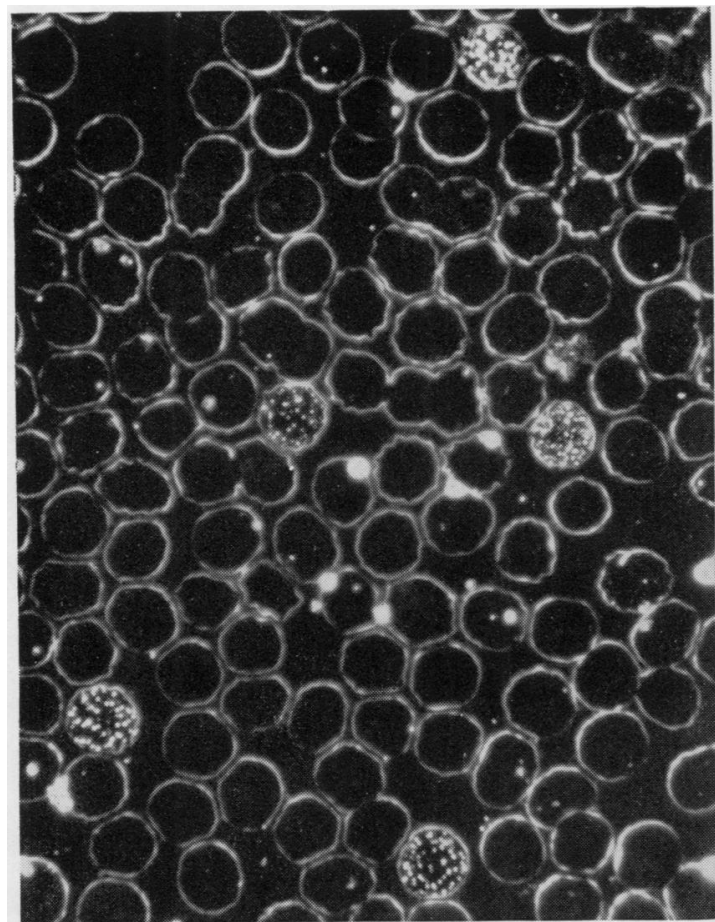

FIG. 1. Erythrocytes stained with new methylene blue showing stippling under dark ground illumination. $\times 1,200$.

sistent results are difficult to attain. A trial of $1 \%$ new methylene blue as an alternative stain produced much clearer definition of the cell outlines and granules and, in consequence, was adopted as a routine (Fig. 1).

It is well recognized that the stippled cell count shows great variation in different films from the same specimen of blood, depending on the speed of drying of the film (Waldron, 1966), as well as varying from one part of the film to another. Our preparations were therefore made under standard conditions as far as possible and the region examined was that part adjacent to the tail of the film in all instances. Furthermore, the figures shown in Table I represent a mean of several counts on the films selected at random to eliminate observer error.

Table I shows a consistent and significant difference between the counts in the blood in anticoagulants and those prepared immediately from capillary or venous blood. This difference was most marked in E.D.T.A. blood and it may be significant that the reduction was apparent after only a short period of contact although it tended to become more marked as the delay in preparing the films increased.

In order to rule out the possibility that stippled

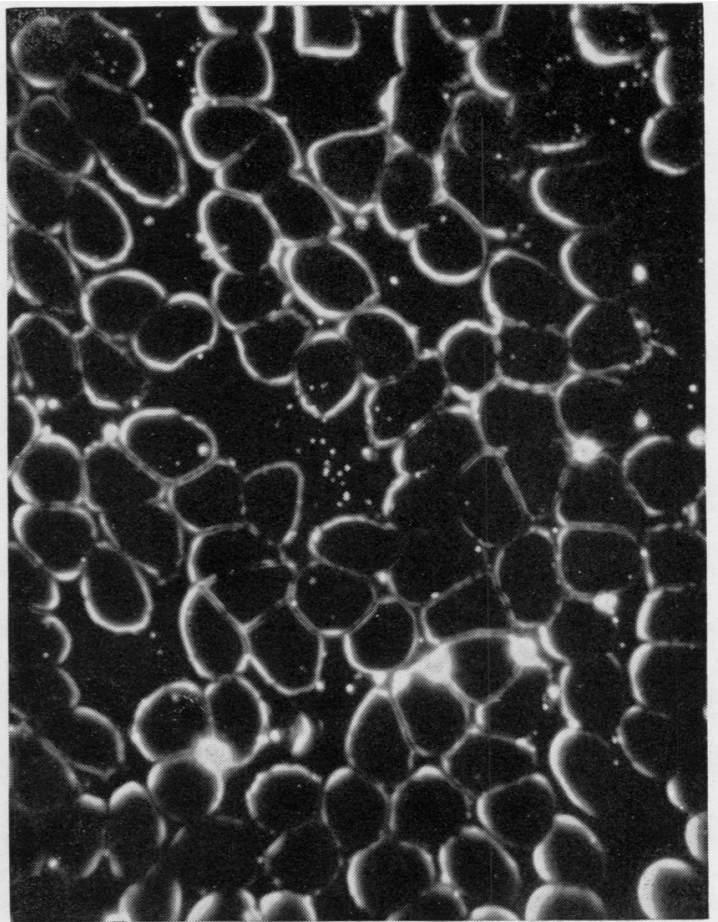

FIG. 2. Erythrocytes washed with normal saline before staining showing discrete groups of free granules. $\times 1,200$.

cells were being lost from the specimen on standing, films were made from defibrinated blood after a delay of an hour, but the cells were found to be present in virtually the same numbers as in freshly drawn blood.

It would, therefore, seem likely that the affected erythrocytes became altered in some way as a result of contact with anticoagulants so that their stippling was lost or at least was no longer demonstrable. This effect was apparent only when the erythrocytes were in suspension, as treatment of the dried fixed films with E.D.T.A. solution did not reduce the count.

In an attempt to reverse this effect of the anticoagulants, E.D.T.A. samples were washed repeatedly with isotonic saline and films prepared of the erythrocyte suspension. It was found, however, that when capillary blood was taken into saline as a control, there was a total absence of stippled cells although in many areas groups of golden granules could be seen lying free amongst the intact erythrocytes (Fig. 2) suggesting rupture of the affected cells.

In the same way as dark ground illumination accentuates the stippling of erythrocytes, it was found that examination of reticulocyte preparations in this way demonstrated the reticular material much 
While urinary coproporphyrin estimations have been suggested in recent years to be a more sensitive index of excessive lead absorption, enumeration of the stippled red cells is still widely used as a more practical method for screening lead workers in industry.

The nature of the reaction of lead in erythrocytes is by no means clear. It was suggested by Aub,
Fairhall, Minot, and Raznikoff (1925), in a classic series of papers, that lead reacted with inorganic phosphate in the substance of the red cell with the liberation of free acid, and damage to the membrane explained the increased mechanical fragility and decreased osmotic fragility which they observed. However, Clarkson and Kench (1958) put forward the view that an insoluble lead phosphate sol forms on the red cell membrane. In a recently published review of lead anaemia, Waldron (1966) concluded that the specific cause is still not known although he suggested that it may well be due to an effect on red cell enzymes, namely, the sulphydryl (-SH) enzymes, which are known to be vulnerable to lead and may be involved in glycolytic reactions on the red cell membrane.

Whatever the mode of action of lead may be, it is now generally accepted that stippled cells are reticulocytes in which the basophilic material has been modified in some way. This view, originally put forward by Whitby and Britton (1933), has recently been confirmed by Jensen and his co-workers (1965) as a result of their optical and electron microscopic studies. Their findings showed that reticulocytes or stippled cells could be produced at will in films by varying the staining technique used and that both, as well as the diffuse basophilia in Romanowsky films, could be abolished by prior treatment with ribonuclease, concluding that all three types of cells were related in some way and all resulted from a ribosomal abnormality.

It appears from the present findings that the numbers of stippled cells on dark ground microscopy are substantially reduced in blood taken into anticoagulants although it seems that these have no such effect after the dried film has been prepared. In view of the rate at which this change is seen it seems unlikely that E.D.T.A. is acting as a chelating agent removing lead from the erythrocytes, for the majority of anticoagulants have the same effect and, if it is true that stippling is due to altered ribosomes, one cannot imagine that the change could be reversed by withdrawal of lead from the cells, especially as it has been shown by Albahary (1945) that more stippled cells are to be found in the marrow than in the peripheral blood, suggesting that lead has its main effect on the red cell precursors rather than circulating erythrocytes.

Although it is impossible to be certain that the 
granules lying free in the film sprepared from salinewashed erythrocytes represent stippled material liberated from cells, their characteristic golden appearance suggests that they are one and the same. If this is so, then their distribution in clusters rather than being evenly dispersed throughout the film suggests that they have been released during the spreading of the film rather than during the washing of the cells. This would be compatible with observations of many workers of an increased mechanical fragility and a reduced osmotic fragility of the erythrocytes in lead poisoning which implies that the stippled cells are more vulnerable to mechanical stresses. Although the effect was also seen in films prepared from saline-washed E.D.T.A. erythrocytes, the frequency of the clusters was far less, suggesting that the effect of E.D.T.A. on stippled cells is not reversible.

Estimates of the serum haptoglobin of workers overexposed to lead did not show any reduction in the levels so that it appears that excessive haemolysis is not an early feature of lead intoxication and this test is consequently of little value in the screening of lead workers.

We wish to thank Professor J. Gough and Dr. H. J. Davies for providing facilities in the preparation of this paper and their encouragement, and to Mr. P. Stinchcombe for the photographs.

\section{REFERENCES}

Albahary, C. (1945). Sang, 16, 341.

Aub, J. C., Fairhall, L. T., Minot, A. S., and Reznikoff, P. (1925). Medicine (Baltimore), $4,1$.

Breecher, G. (1949). Amer. J. clin. Path., 19, 895.

Clarkson, T. W., and Kench, J. E. (1958). Brit. J. industr. Med., 15, 115.

Jensen, W. N., Moreno, G. D., and Bessis, M. C. (1965). Blood, 25, 933.

Lane, R. E. (1949). Brit. J. industr. Med., 6, 125.

Rowe, D. S. (1961). J. clin. Path., 14, 205.

Waldron, H. A. (1966). Brit. J. industr. Med., $23,83$.

Whitby, L. E. H.. and Britton, C. J. C. (1933). Lancet, 1, 1173. 